\title{
PENERAPAN METODE ANALITYCAL HIERARCHY PROCESS UNTUK PEMILIHAN SISWA TERBAIK PADA SMP MANBA’UL ULUM ASSHIDDIQIYAH JAKARTA
}

\author{
Syifa Elfrida ${ }^{1)}$, Goenawan Brotosaputro ${ }^{2)}$ \\ ${ }^{1}$ Sistem Informasi, Fakultas Teknologi Informasi, Universitas Budi Luhur \\ ${ }^{1,2} \mathrm{Jl}$. Raya Ciledug, Petukangan Utara, Kebayoran Lama, Jakarta Selatan 12260 \\ E-mail: syifa.elfrida97@gmail.com ${ }^{1)}$, goenawan.brotosaputro@budiluhur.ac.id ${ }^{2)}$
}

\begin{abstract}
Abstrak
Dalam hal kualitas pendidikan, SMP Manba'ul Ulum Assiddiqiyah berusaha memajukan kualitasnya. Terutama dengan melakukan pemilihan siswa terbaik disetiap kelasnya. Namun ada beberapa masalah yang ada didalam pemilihan siswa terbaik adalah bagian Tata Usaha sulit melihat rekap penilaian siswa dikarenakan belum adanya sistem untuk menampung data penilaian siswa . Sehingga penilaian masih mengunakan perkiraan.. Untuk menyelesaikan masalah tersebut, maka diperlukannya Sistem Penunjang Keputusan pemilihan siswa terbaik pada SMP Manba'ul Ulum Asshiddiqiyah Jakarta. Dengan penelitian ini, metode yang cocok digunakan adalah metode Analytical Hierachy Process (AHP), metode ini dipilih karena dapat memberikan hasil optimum kepada sekolah dalam memilih siswa yang terbaik. Sebagai metode pengambilan keputusan ini terdapat beberapa kriteria yaitu jumlah nilai, absensi, akhlak, kepribadian, ekskul dalam bentuk kuesioner. Dengan itu dapat membantu dan mempermudah dalam menentukan hasil keputusan yang berkaitan dengan masalah penentuan siswa terbaik pada SMP Manba’ul Ulum Asshiddiqiyah Jakarta.
\end{abstract}

Kata kunci: SPK, AHP, Siswa

1. PENDAHULUAN

1.1. Latar Belakang

SMP Manba'ul Ulum Assiddiqiyah adalah Salah Satu Yayasan Pondok Pesantren Assiddiqiyah pusat yang ada di Jakarta. Dalam hal kualitas pendidikan, SMP Manba'ul Ulum Assiddiqiyah berusaha memajukan kualitasnya. Terutama dengan melakukan pemilihan siswa terbaik disetiap kelasnya. Pemilihan ini dilakukan dua kali setiap tahun pada setiap semester. Hal ini ditujukan agar siswa termotivasi untuk belajar dengan giat agar mendapat sertifikat dari sekolah sebagai reward untuk prestasi yang telah diraih siswa. Dengan adanya reward tersebut, SMP Manba'ul Ulum Assiddiqiyah berharap agar siswa/i bisa termotivasi dan lebih bersemangat lagi untuk meraih prestasi dan menggapai cita-cita.

Adapun beberapa masalah yang terjadi pada SMP Manba'ul Ulum Asshiddiqiyah dalam menentukan siswa terbaik yaitu bagian Tata Usaha sulit melihat rekap penilaian siswa dikarenakan belum adanya sistem untuk menampung data penilaian siswa. Sehingga masih menggunakan microsoft excel dan pencatatan tangan. Sehingga penilaian masih mengunakan perkiraan. Serta SMP Manba'ul Ulum Assiddiqiyah belum bisa menentukan metode untuk banyaknya kriteria.

Berdasarkan uraian masalah diatas, penulis dapat melandasi bahwa dalam menyusun jurnal ini yang berjudul " PENERAPAN METODE ANALITYCAL HIERARCHY PROCESS UNTUK
PEMILIHAN SISWA TERBAIK PADA SMP MANBA'UL ULUM ASSHIDDIQIYAH JAKARTA.”. Hal ini dilakukannya pemilihan siswa terbaik pada SMP Manba'ul Ulum Asshiddiqiyah Jakarta akan mengasilkan nilai bobot kriteria dan nilai bobot alternatif yang sudah dikalikan dan akan menghasilkan hasil Perangkingan. Sehingga ditentukanlah pemilihan siswa terbaik pada SMP Manba'ul Ulum Asshiddiqiyah.

\subsection{Definisi Sistem Penunjang Keputusan}

Definisi dari Decision Support System (DSS) atau sistem penunjang keputusan adalah salah satu sistem yang diartikan untuk membantu para penentuan hasil keputusan manajemen dalam keadaan keputusan semi terstruktur.

Dibangunnya Sistem Pendukung Keputusan ini biasanya untuk membantu menyelesaikan masalah [1]. Aplikasi SPK menggunakan CBIS yang adaptif, yang saling aktif dan dapat diadaptasi, dan dikembangkan untuk mendukung solusi atas masalah manajemen tertentu yang tidak terstruktur.

\section{PENELITIAN SEBELUMNYA}

2.1. Definisi Metode AHP

Metode AHP ini pada dasarnya didesain untuk menangkap secara pemahaman yang logis pada seseorang yang hubungannya sangat dekat dengan masalah tertentu melalui metode yang didesain untuk sampai pada suatu skala preferensi diantara 
beraneka macam alternatif. Analisa ini dianjurkan untuk membuat suatu model perselisihan yang tidak memiliki struktur, biasa ditentukan untuk menyelesaikan masalah yang terukur kuantitatif), masalah yang memerlukan pendapat (pertimbangan) maupun pada keadaan yang rumit atau tidak terkerangka, pada keadaan dimana data, informasi statistik sangat minimum yang hanya bersifat kualitatif (huruf) yang berdasarkan oleh penangkapan, ataupun pengalaman. Metode ini juga kebanyakan digunakan pada keputusan yang banyak kriterianya, perancangan, sumberdaya dan penentuan yang diutamakan dari langkah-langkah yang dimiliki pemain dalam situasi permasalahan [2].

\subsection{Teori Pendukung}

\section{a. Pengertian Siswa}

Siswa merupakan anggota masyarakat yang berusaha meningkatkan kemampuan pribadi dalam proses belajar pada alur pendidikan baik pendidikan resmi maupun pendidikan tidak resmi, pada tahap pendidikan dan macam-macam pendidikan tertentu. Siswa ialah istilah peserta didik pada tahap pendidikan mendasar dan pendidikan menengah [3].

\section{b. Pengertian Reward}

Reward adalah penghargaan atas suatu dan menguntungkan bagi perusahaan. Dengan diadakannya adalah untuk memotivasi siswa supaya dapat meningkatkan belajar disekolah supaya siswa mendapatkan apa yang di raih atau dicita-citakan.

\subsection{Studi Literatur}

Terkait pada penelitian ini dengan penentuan siswa terbaik telah banyak dilakukan, beberapa diantaranya menggunakan metode AHP. Saat ini pemilihan siswa terbaik adalah suatu kebutuhan yang baik untuk sekolah, siswa, guru ataupun demi kepentingan siswa sendiri.Yang Pertama seperti penelitian yang berjudul Sistem Pendukung Keputusan Pemilihan Siswa Terbaik di STMIK Bina Insani Dengan Metode AHP. Pemilihan siswa terbaik salah satunya bisa digunakan untuk mempertimbangkan apakah siswa tersebut pantas untuk mendapatkan reward atau apakah siswa tersebut layak untuk mendapatkan sertifikat siswa terbaik. Diharapkan dengan adanya pemilihan siswa terbaik semakin memotivasi dalam menaikkan kualitasnya, yang akhirnya dengan meningkatkan kualitas pendidika siswa, siswa yang berkualitas, unggul dan berprestasi akan semakin bermunculan [2]. Penelitian selanjutnya dilakukan oleh dalam jurnal ISSN: 2088-3943 yang berjudul "Sistem Pendukung Keputusan Pemilihan Siswa Berprestasi pada SMK Singosari Delitua Dengan Menggunakan Motode Analytical Hierarchy Procces (AHP)". Menjadi siswa berprestasi adalah impian setiap siswa di sekolah. Prestasi yang didapat tentu didasarkan dengan suatu kemampuan terhadap pengetahuan yang dimiliki oleh masing-masing siswa. Untuk itu, sekolah selalu mendorong meningkatkan kualitas dan semangat dalam belajar disekolah. Pembuatan sistem pendukung keputusan ini merupakan salah satu cara untuk membantu dalam melakukan pemilihan siswa terbaik pada SMK Singosari Delitua. Kriteria yang dinilai dalam pemilihan siswa terbaik meliputi kedisiplinan, tes akademik, tes kejujuran, IQ [4]. Berikutnya penelitian yang menggunakan Analytical Hierarchy Process (AHP) dalam jurnal Vol.2 No.2, September 2015 / ISSN: 2406-7733 dengan judul "Sistem Pendukung Keputusan Pemilihan Siswa Berprestasi SMPN 1 Kota Serang Dengan Menggunakan Analitycal Hierarchy Process (AHP)". Pemilihan siswa berprestasi di SMP Negeri 1 Kota Serang sangat penting dalam rangka pemberian beasiswa . Untuk menentukan siswa berprestasi membutuhkan proses pengambilan keputusan yang tidak mudah karena melibatkan banyak kriteria seperti Data Absensi (Alpha, Hadir, Ijin, Sakit), Nilai Raport (UAS, UH, UTS), Tingkah Laku (Akhlak dan Kepribadian) [5].

\section{METODE PENELITIAN}

\subsection{Metode Pengumpulan Data}

Pada pengumpulan data pada tugas akhir ini dapat dilakukan melalui observasi, wawancara, analisa dokumen, dan studi pustaka, dan kuesioner.

a) Observasi

Kegiatan observasi ini dapat dilakukan untuk mengumpulkan data dengan cara bertatapan muka dengan hal yang kaitannya dengan proses penentuan siswa terbaik pada SMP Manba'ul Ulum Asshiddiqiyah sebagai masukan untuk tugas akhir ini.

b) Wawancara

Dengan melakukan metode ini dapat menyampaikan pertanyaan yang berhubungan dengan proses pemilihan siswa terbaik di SMP Manba'ul Ulum Asshiddiqiyah. Sehingga penulis mendapatkan dokumen berjalan yang dapat digunakan dalam perkembangan SPK pemilihan siswa terbaik pada tugas akhir ini.

c) Analisa Dokumen

Analisa dokumen ini dapat dilakukan untuk menganalisis dokumen yang berjalan supaya memperoleh informasi yang pas dengan sistem yang akan dipakai pada tugas akhir ini.

d) Studi Pustaka

Kegiatan Studi Pustaka ini peneliti dapat membaca jurnal, buku ataupun referensi orang lain yang berkaitan pada teori penentuan siswa terbaik, Sistem AHP. 
e) Kuesioner

Pengertian dari kuesioner ini adalah cara mengumpulkan data untuk diketahui tanggapannya dari responde pada pertanyaan yang diberikan. Kuesioner yang diperoleh dari informan, didapatkan suatu hasil yang akan digunakan unutk penghitungan kriteria pada pemilihan siswa terbaik pada SMP Manba'ul Ulum Asshiddiqiyah.

\section{HASIL DAN PEMBAHASAN}

\subsection{Analisa Masalah}

Didalam analisa masalah pada penentuan keputusan dalam memilih siswa terbaik di SMP Manba'ul Ulum Asshiddiqiyah Jakarta, masalah utamanya adalah pemilihan siswa terbaik belum tepat karena ada beberapa bagian antara lain bagian manusia, proses, dan metode. Dibagian manusia berakibat sulit dalam menentukan siswa terbaik yang disebabkan oleh penilaian akhir yang sama. Faktor proses mengakibatkan proses rekapan riwayat pengambilan keputusan yang lalu tidak direkap, dikarenakan administrasi dan dokumentasi belum baik. Sedangkan faktor metode mengakibatkan sulit menentukan prioritas kriteria disebabkan karena belum adanya pembobotan pada kriteria yang ditampilkan pada Gambar 1: Fishbone Diagram.

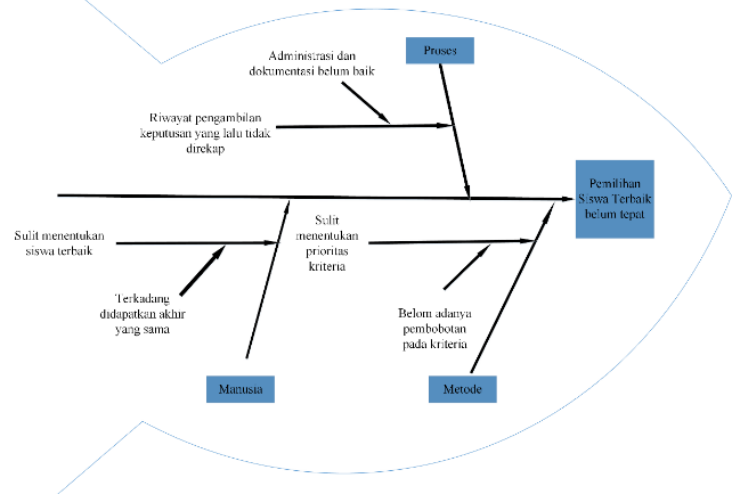

Gambar 1: Fishbone Diagram

\subsection{Proses Bisnis Berjalan}

Proses pemilihan siswa terbaik pada SMP Manba'ul Ulum melakukan dua kali setiap tahunnya yaitu setiap akhir semester ganjil dan genap. Pada proses pemilihan ini memulai dari walikelas membuat data nilai para siswa di Leger Raport Diknas didalam microsoft excel. Lalu walikelas menentukan 1 siswa disetiap kelasnya yang dilandasi nilai raport paling tinggi atau peringkat atas. Data nilai tersebut selanjutnya akan diberikan kepada bagian TU untuk dilakukannya pemilihan siswa terbaik disetiap kelasnya. Setelah bagian Tata Usaha membuat data pemilihan siswa terbaik, selanjutnya diserahkan kepada Kepala Sekolah untuk diadakan rapat menentukan siswa terbaik. Setelah diadakannya rapat lalu Kepala Sekolah telah menentukan siswa terbaik dan terpilihnya siswa terbaik akan mendapatkan reward dari sekolah berupa sertifikat prestasi ditampilkan pada Gambar 2: Activity Diagram Proses Bisnis pemilihan siswa terbaik.

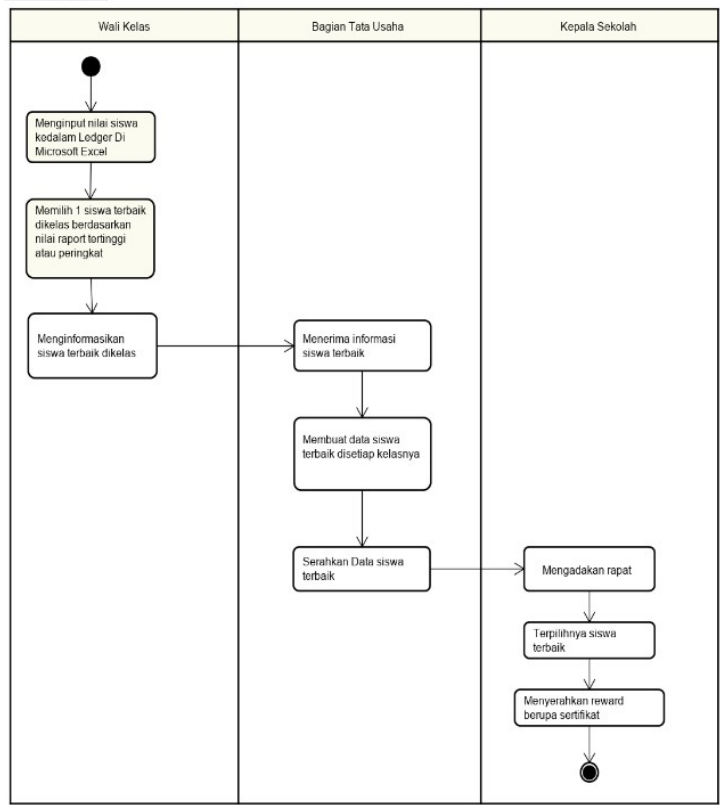

Gambar 2: Activity Diagram Proses Bisnis pemilihan siswa terbaik

\subsection{Model Keputusan Dengan AHP}

Metode AHP yang dikembangkan dari Universitas Pitssburg pada tahun 1970an oleh Dr. Thomas L. Saaty dapat mengkonfigurasikan informasi dan penilaian terhadap pemilihan alternatif yang paling diminati. AHP membantu dalam menentukan yang diutamakan dari beberapa kriteria dengan melakukan analisis perbandingan berpasangan dai masing-masing kriteria. Analytical Hierarchy Process ini bergantung kepada visi, keahlian dan pemahaman untuk persoalan yang mampu disusun, dan juga memberikan perkiraanperkiraannya. AHP ini menggunakan model hirarki yang terdiri dari maksud tujuan, kriteria, beberapa subkriteria dan alternatif untuk permasalahan yang sedang dihadapi. Dengan digunakannya hierarki, permasalahan yang rumit dapat dijabarkan menjadi langkah-langkah yang lebih gampang dan dimengerti. Kemudian langkah-langkah tersebut diberikan masukan berupa pertimbangan ahli dan diselesaikan dengan proses aritmatika yang gampang untuk mengurutkan yang diutamakan sehingga dapat dijadikan untuk mendukung proses pengambilan keputusan. AHP yang dipergunakan untuk melorotkan skala rasio dari beberapa bandingan pasangan yang bersifat gabungan ataupun 
berkelanjutan. Perbandingan berpasangan tersebut dapat diperoleh melalui pengukuran aktual maupun pengukuran sepadan dari tingkatan yang disukai atau ya dipentingkan. Dengan demikian metode ini berguna untuk membantu memperoleh skala rasio dari hal yang awalnya sulit diukur dari pendapat, perasaan, perilaku, dan kepercayaa. Analytical Hierarchy Process (AHP) memungkinkan pakar (ahli) untuk memberikan niali bobot relatif dari suatu kriteria berbagai macam dengan melkukan perbandingan berpasangan.. Yang dihasilkan dari perbandingan pasangan kriteria ini dapat membentuk matrik, dimana skala rasio diturunkan kedalam bentuk eigen vector utama ataupun fungsi eigen. Matrik yang berdiri positif dan kebalikan, yaitu $a_{i j}=$ 1/ $a_{i j}$. Gambar 3: Struktur Hierarki Pemilihan Siswa Terbaikmenunjukan struktur hierarki permasalahan yang ingin disaksama adalah penentuan siswa terbaik yang terpilih atau yang terbaik berdasarkan beberapa kriteria. Penentuan kriteria memperoleh dari data yang ada di SMP Manba'ul Ulum Asshiddiqiyah Jakarta.

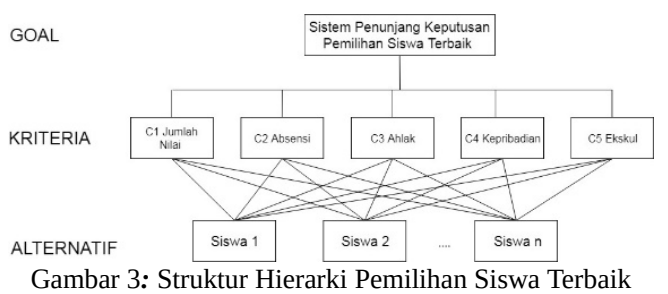

\section{a. Identifikasi Goal}

Tujuan dari hirarki pada Gambar 3: Struktur Hierarki Pemilihan Siswa Terbaik adalah pemilihan siswa terbaik dari Kelas 8.1, 8.2, 8.3, 8.4, 8.5 pada SMP Manba'ul Ulum Asshiddiqiyah Jakarta. Berdasarkan kriteria ada maka akan dilakukan perbandingan berpasangan antara langkah-langkah. Kemudian akan memperoleh bobot untuk tiap-tiap kriteria. Lalu untuk menentukan perhitungan antara alternatif dengan kriteria tiap-tiap dilakukan dengan metode AHP.

b. Identifikasi Kriteria

Berikut adalah kriteria yang digunakan dalam pemilihan siswa terbaik di SMP Manba'ul Ulum Asshiddiqiyah Jakarta.

1) Jumlah Nilai

Kriteria ini adalah penilaian kuantitatif (berupa angka) terhadap kemampuan siswa dalam menerima tugas-tugas atau ulangan yang telah diberikan oleh guru.

2) Absensi

Kriteria ini adalah penilaian kuantitatif (berupa angka) yang menunjukan pada jumlah hadir pertahunnya dalam mengikuti proses belajar disekolah.

3) Nilai Akhlak
Kriteria ini adalah penilaian kualitatif (berupa huruf) terhadap bagaimana cara siswa-siswi bersikap kepada temantemannya dan guru-guru dilingkungan sekolah.

4) Nilai Kepribadian

Kriteria ini adalah penilaian kualitatif (berupa huruf) terhadap bagaimana cara siswa berkepribadian kepada teman dan guru dilingkungan sekolah.

5) Nilai Ekskul

Kriteria ini adalah penilaian kualitatif (berupa huruf) terhadap kemampuan siswa dalam melakukan kegiatan ekskul yang telah diberikan oleh guru.

c. Identifikasi Alternatif

Data alternatif berasal dari siswa SMP Manba'ul Ulum Asshiddiqiyah yang akan dipilih berdasarkan kriteria yaitu Jumlah nilai >=1000, Absensi dalam jumlah hadir $=100 \%$, Akhlak, Kepribadian, dan Ekskul.

a) Penilaian perbandingan kepentingan antar kriteria.

Dibawah ini adalah penilaian perbandingan kepentingan antar kriteria yang digunakan sebagai dasar pemilihan siswa terbaik pada SMP Manba'ul Ulum Asshiddiqiyah Jakarta.

1) Jumlah nilai sama penting dari Absensi.

2) Jumlah nilai 2 (lima) kali lebih penting dari Akhlak.

3) Jumlah nilai 2 (lima) kali lebih penting dari Kepribadian.

4) Jumlah nilai sama penting dari Ekskul.

5) Absensi sama penting dari Ahklak.

6) Absensi 2 (empat) kali lebih penting dari Kepribadian.

7) Absensi sama penting dari Ekskul.

8) Akhlak 2 (dua) kali lebih penting dari Kepribadian.

9) Akhlak sama penting dari Ekskul.

10)Kepribadian 2 (dua) kali lebih penting dari Ekskul.

Berikut Matriks Perbandingan Kepetingan antar Kriteria dapat dilihat pada Tabel 1: Matriks Perbandingan Kepentingan Per Kriteria.

Tabel 1: Matriks Perbandingan Kepentingan Per Kriteria

\begin{tabular}{|l|c|c|c|c|c|}
\multicolumn{1}{|c|}{ Kriteria } & $\begin{array}{c}\text { Jumlah } \\
\text { nilai }\end{array}$ & Absensi & Akhlak & Kepribadian & Ekskul \\
\hline Jumlah nilai & 1 & 1 & $1 / 2$ & 2 & 1 \\
\hline Absensi & 1 & 1 & 1 & $1 / 2$ & 1 \\
\hline Akhlak & 2 & 1 & 1 & 2 & 1 \\
\hline Kepribadian & $1 / 2$ & 2 & $1 / 2$ & 1 & 2 \\
\hline Ekskul & 1 & 1 & 1 & $1 / 2$ & 1 \\
\hline
\end{tabular}

Step-step dalam menentukan pembobotan tiaptiap kriteria dengan model AHP adalah sebagai 
berikut:

1) Langkah 1

Menjabarkan matriks diatas kedalam bentuk desimal:

$\left[\begin{array}{lllll}1,0000 & 1,0000 & 0,5000 & 2,0000 & 1,0000 \\ 1,0000 & 1,0000 & 1,0000 & 0,5000 & 1,0000 \\ 2,0000 & 1,0000 & 1,0000 & 2,0000 & 1,0000 \\ 0,5000 & 2,0000 & 0,5000 & 1,0000 & 2,0000 \\ 1,0000 & 1,0000 & 1,0000 & 0,2000 & 1,0000\end{array} \mid\right.$

2) Langkah 2

$[5,00002,00001,00002,00001,0000][5,00002,00001,00002,0 c$ $1,00001,00001,00000,50001,0000 \quad 1,00001,00001,00000,5 \mathrm{C}$ $2,00001,00001,00002,00001,0000 \times 2,00001,00001,00002,0 C$ $0,50002,00000,50001,00002,0000 \quad 0,50002,00000,50001,0 c$ $1,00001,00001,00000,20001,0000$ 1,0000 1,00001,00000,2C

3) Langkah 3

Berikut Hasil dari perkalian matrik:

$\left[\begin{array}{lllll}5,0000 & 7,5000 & 4,0000 & 6,0000 & 7,5000 \\ 5,2500 & 5,0000 & 3,7500 & 5,5000 & 5,0000 \\ 7,0000 & 9,0000 & 5,0000 & 9,0000 & 9,0000 \\ 6,0000 & 7,0000 & 5,2500 & 5,0000 & 7,0000 \\ 5,2500 & 5,0000 & 3,7500 & 5,5000 & 5,0000\end{array}\right]$

4) Langkah 4

Berikut menjumlahkan masing-masing baris hasil dari perkalian matrik :
30,0000
24,5000
39,0000
30,2500
24,5000
148,2500

\section{b) Hasil Perbandingan Kepentingan}

\section{Alternatif kriteria Jumlah nilai}

1) Pembagian masing-masing jumlah baris pada matrik dengan total baris yang akan menghasilkan eigenvector.

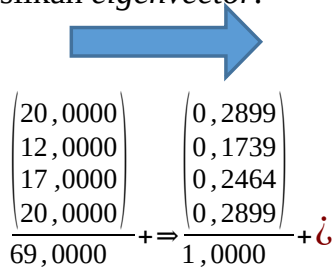

2) Dapat Menentukan bobot dari masing-masing kriteria yang diambil dari Eigenvector.

A1 $=0,2899$

$\mathrm{A} 2=0,1739$

A3 $=0,2464$

$\mathrm{A} 4=0,2899$

\section{c) Hasil Penelitian (Perangkingan)}

Hasil Perangkingan ini dapat di hitung dari Bobot Kriteria dikali dengan Bobot Alternatif, sehingga dapat dilihat pada Tabel 2: Hasil Perangkingan Bobot Kriteria dan Alternatif.
Tabel 2: Hasil Perangkingan Bobot Kriteria dan Alternatif

\begin{tabular}{|l|l|l|l|l|l|}
\hline Alternatif & \multicolumn{5}{|c|}{ Bobot Alternatif } \\
\hline Al & 0,2899 & 0,1140 & 0,1722 & 0,1391 & 0,1545 \\
\hline A2 & 0,1739 & 0,4136 & 0,2914 & 0,3974 & 0,2432 \\
\hline A3 & 0,2464 & 0,2058 & 0,3311 & 0,2318 & 0,2818 \\
\hline A4 & 0,2899 & 0,2366 & 0,2053 & 0,2318 & 0,3205 \\
\hline \multicolumn{7}{|c|}{ Bobot Kriteria } \\
\hline \multicolumn{7}{|c|}{0} \\
\hline & 0,2024 & 0,1653 & 0,2631 & 0,2040 & 0,1653 \\
\hline \multicolumn{7}{|c|}{} \\
\hline \multicolumn{7}{|c|}{0,3015} & 0,2649 & 0,2521 & \\
\hline
\end{tabular}

\subsection{ERD (Entity Relationship Diagram)}

Berikut adalah ERD pemilihan siswa terbaik pada SMP Manba'ul Ulum Asshiddiqiyah Jakarta. Yang ditampilkan pada Gambar 4: ERD (Entity Relationship Diagram)

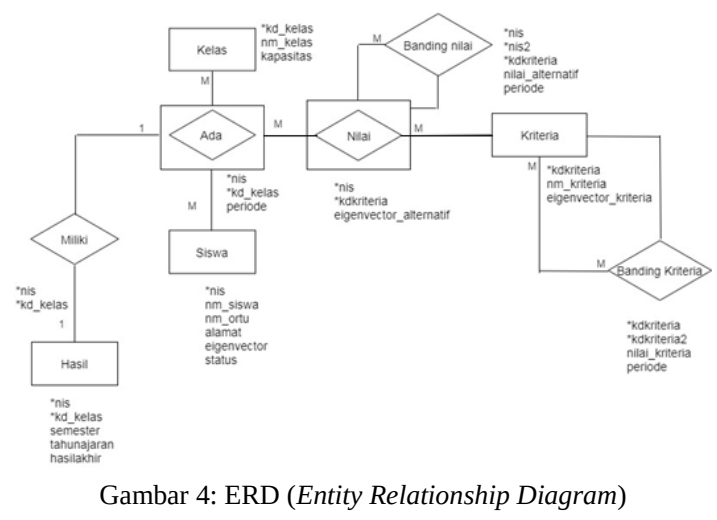

\subsection{Perancangan Sistem (Use case Diagram)}

Dibawah ini terdapat tiga Use Case diagram yang terbagi dalam Data Master, Analisa, dan Laporan yang ditampilkan pada Gambar 5: Use Case Diagram Data MasterGambar 5: Use Case Diagram Data Master, Gambar 6: Use Case Diagram Analisa, dan Gambar 7: Use Case Diagram Laporan. Pada Gambar 5: Use Case Diagram Data Master terdiri atas Entri Data Siswa, Entri Data Kelas dan Entri Data Kriteria . Pada Gambar 6: Use Case Diagram Analisa terdiri atas Entri Analisa Kriteria, Entri Analisa Alternatif, Lihat Perangkingan dan Lihat Hasil Keputusan. Sedangkan pada Gambar 7, terdiri atas modul Cetak Laporan Hasil Keputusan dan Cetak Laporan Perangkingan.

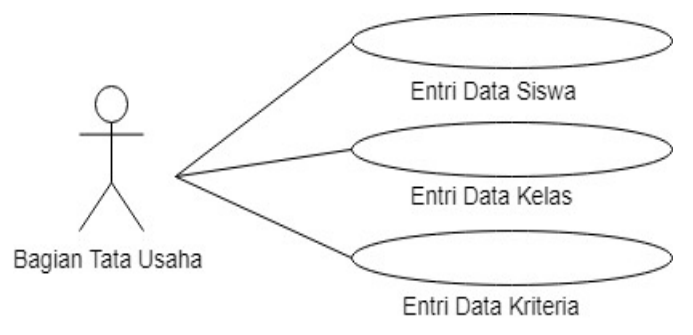

Gambar 5: Use Case Diagram Data Master

Pada Gambar 5: Use Case Diagram Data Master menjelaskan bahwa Bagian TU dapat 
mengentri data siswa,entri data kelas dan entri data kriteria.
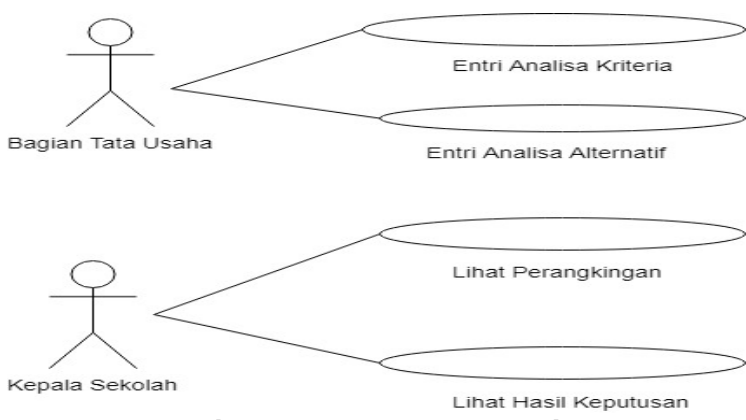

Gambar 6: Use Case Diagram Analisa

Pada Gambar 6: Use Case Diagram Analisa menjelaskan bahwa Bagian TU dapat mengentri Analisa Kriteria dan entri Analisa Alternatir. Kemudian Kepala Sekolah dapat melihat hasil perangkingan dan hasil keputusan.

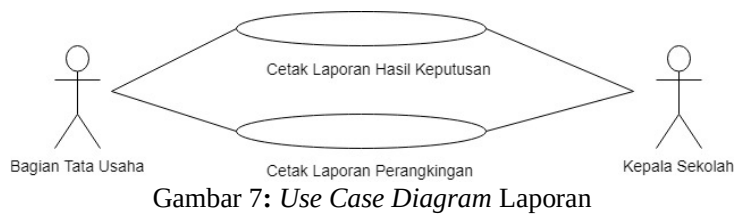

Pada Gambar 7: Use Case Diagram Laporan menjelaskan bahwa Bagian TU dapat mencetak laporan hasil keputusan dan cetak laporan perangkingan, kemudian Kepala sekolah menerima hasil keputusan dan perangkingan.

\subsection{Rancangan Layar}

a. Menu Utama

Dimenu utama dibawah ini terdapat submenu Data Master, Analisa dan Laporan. Pada menu data master terdapat submenu entri data siswa, entri data kelas dan entri data kelas yang ditampilkan pada Gambar 8: Rancangan Layar Menu Utama. Pada submenu analisa terdapat submenu entri analisa kriteria, entri analisa alternatif, submenu hasil keputusan dan submenu perangkingan. Pada menu laporan terdapat submenu cetak laporan hasil keputusan dan cetak perangkingan.

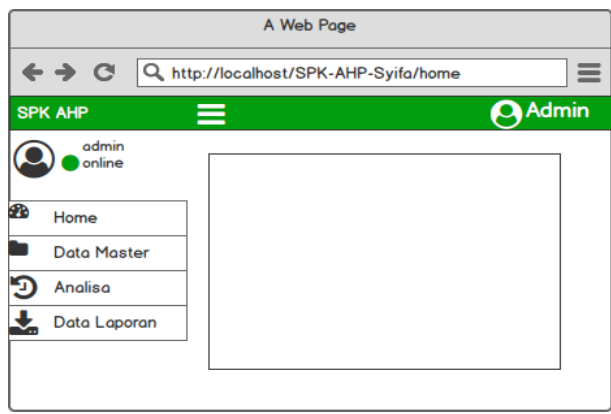

Gambar 8: Rancangan Layar Menu Utama

Pada Gambar 8: Rancangan Layar Menu Utama menjelaskan bahwa Admin dapat menampilkan menu utama.

b. Entri Data Siswa

Pada menu Input pilih submenu Entri data siswa yang dapat digunakan untuk memasukan identitas siswa. Yang ditampilkan pada Gambar 9: Rancangan Entri Data Siswa.

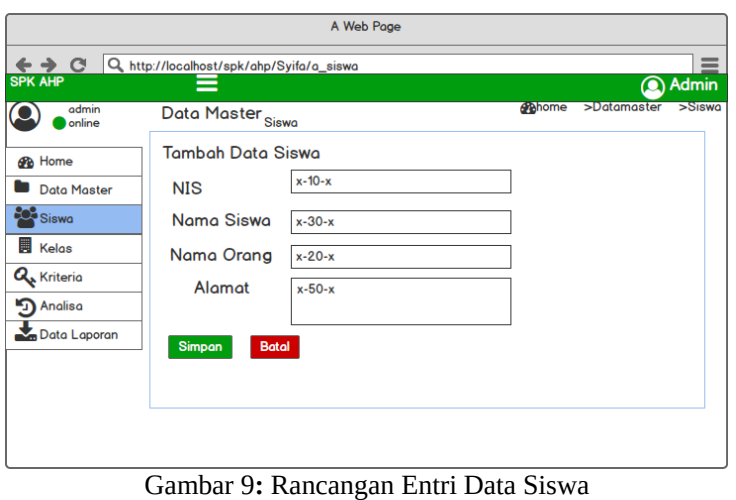

Pada Gambar 9: Rancangan Entri Data Siswa menjelaskan bahwa Admin dapat menampilkan menu Siswa yang berisi data Master Siswa.

c. Menu Tampil Data Analisa Kriteria

Pada menu tampil analisa pilih submenu Analisa Kriteria ditampilkan pada Gambar 10: Rancangan layar Menu tampil analisa kriteria.

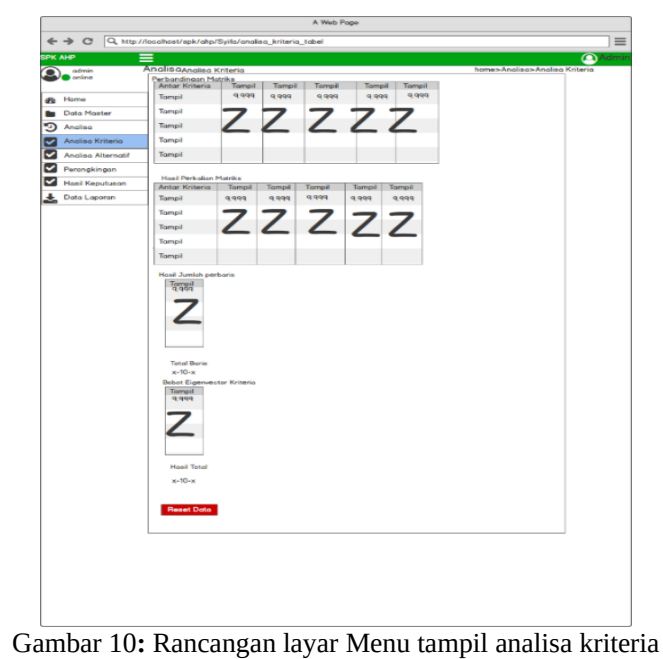

Pada Gambar 10: Rancangan layar Menu tampil analisa kriteria menjelaskan bahwa Admin menampilkan Menu Analisa yang berisi Analisa Perbandingan Kriteria.

d. Cetak Laporan Hasil Keputusan Siswa Terbaik

Pada menu Laporan pilih submenu laporan hasil keputusan. Yang ditampilkan pada Gambar 11: Rancangan Layar Cetak Laporan Pemilihan Guru Terbaik. 


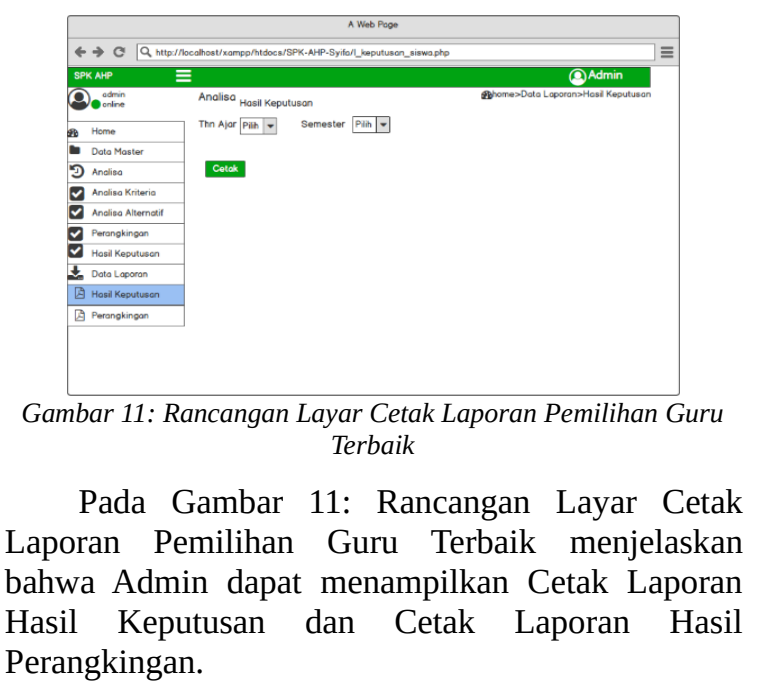

\section{KESIMPULAN}

Terdapat beberapa kesimpulan yang dapat diambil pada penelitian yang telah dilakukan di SMP Manba'ul Ulum Asshiddiqiyah Jakarta, yaitu:

a. Dengan metode AHP dapat diketahui kriteria yang paling unggul, sehingga dalam pemilihan siswa terbaik, kriteria yang paling menentukan adalah kriteria akhlak dengan bobot 0,2631.

b. Perhitungan pada pembobotan kriteria pemilihan siswa terbaik dilakukan menggunakan metode Analytical Hierarchy Proess dengan dilakukannya perbandingan nilai antar kriteria yang berdasarkan kuesioner yang telah diisi oleh kepala sekolah SMP Manba'ul Ulum Asshiddiqiyah Jakarta.

c. Proses perangkingan siswa dapat dihitung dengan menggunakan metode AHP yang hitungannya bobot kriteria yang sudah dihitung penilaian kepentingan antar kriterianya di kali dengan nilai alternatifnya dengan metode AHP.

\section{DAFTAR PUSTAKA}

[1] F. Susanto, "Sistem Pendukung Keputusan Penentuan Siswa / i Lulusan Terbaik Di Sekolah Menengah Kejuruan Negeri 1 Kotabumi Menggunakan Metode Analytical Hierarchy Process,” vol. 02, no. 01, 2019.

[2] J. M. Penusa, B. Sinaga, H. M. Zebua, S. Utara, I. Pendahuluan, and S. M. Pertama, "Sistem Pendukung Keputusan Pemilihan Siswa Berprestasi Menggunakan Metode Analytical Hierarchy Process ( AHP ) Pada SMK Singosari Delitua,” vol. 16, no. 2, pp. 1-11, 2014.

[3] D. K. Dewi, S. M. A. Negeri, and K. Rakyat, "Sistem Pendukung Keputusan Dalam Menentukan Siswa siswi terbaik SMA Negeri 1 Kampung Rakyat Menggunakan Metode Topsis,” vol. 17, pp. 283288, 2018.

[4] S. Rahmatullah, D. S. Purnia, and R. Hariyadi, "Sistem Pendukung Keputusan Pemilihan
Smartphone Android Gaming Dengan Metode Analytical Hierarchy Process,” J. Kaji. Ilm., vol. 18, no. 3, p. 283, 2018.

[5] R. Wijaya et al., "Pada Sekolah Menengah Pertama Dengan Menggunakan Metode Analytical Hierarchy Process (AHP),” vol. 2, no. 2, 2015. 